\title{
DETECTION OF THE NITRATE POLLUTION SOURCES IN SHALLOW AQUIFER, USING INTEGRATION OF RS\&GIS WITH STABLE ISOTOPES TECHNOLOGIES
}

\author{
Nadia Babiker Ibrahim Shakak \\ Ministry of Water Resources, Irrigation and Electricity, Ground Water and Wades' General Directorate; Omdurman University, \\ UNESCO Chair on Water Resource Science, Sudan Remote Sensing and Seismological Authorities, Khartoum Sudan, \\ Email: Shakak63@gmail.com
}

KEY WORDS: Mosaic image, Nitrate, Pollution, Sources, Anthropogenic, Gogebic, Shallow aquifer, Stable isotopes

\begin{abstract}
:
Geographical information system (GIS) and remote sensing technique is a tool which is used for acquiring data from space, storing, analyzing and displaying spatial data, also can use for investigating source of environmental pollution which is affect health. Sudan landsat mosaic image which acquired in 2013 was used in this study to develop land use and land cover maps for tow selected study area, Khartoum urban area, and Bara locality in North kordofan state western Sudan. The main objective to assess the source of Nitrate pollution in shallow aquifer. ERDAS software was used to create land cover-land use maps for the study areas. For Khartoum town we used land sat mosaic image which acquire in 2013, and used supervised classification which more closely controlled than unsupervised. In this process, we select pixel that represent patterns you recognized or can identify with help from knowledge of the data, the classes desired, and the algorithm to be used is required. In this paper we integrated the (GIS\&RS), and stable isotopes methods for fingerprinting Nitrate sources in shallow boreholes. The global positioning system (GPS), used in the field to identify the shallow boreholes location in a three dimensional coordinate (Latitude, longitude, and altitude), Water samples were collected from 19 shallow boreholes in the study areas according to the standard sampling method send to laboratory to measure stable nitrogen ( $\delta 15 \mathrm{Nnitrate})$, and Nitrate-oxygen ( $\delta 18 \mathrm{Onitrate})$ isotopes. Analysis were conducted by using isotope ratio mass spectrometry (IRMS). We can conclude that, special distribution and integration of GIs \& RS help to identify the source of nitrate pollution.
\end{abstract}

\section{INTRODUCTION}

Contamination of shallow ground water by nitrate (NO3-) from various sources continues to be a problem through much of the Bara area, most nitrate contamination sources are easily defined, particularly if there is a single known source such as a cattle feed lot and small farms, but in some areas - particularly rural locations that have been urbanized, distinguishing between human (anthropogenic) and natural (geogenic) sources is somewhat more complicated. The main concern with high levels of nitrate in groundwater is the increased incidence of methemoglobinemia, known as blue-baby disease; it causes the child to develop a bluish or grayish tint around the extremities. If left untreated the baby will not receive enough oxygen through the blood and could die. This problem arises primarily in rural areas. How can one distinguish between anthropogenic and geogenic nitrate? Conventional nitrate analysis only gives quantitative data and does not discriminate between sources. However, if one examines the stable isotopes of nitrate, unique fingerprints for different sources can be obtained. Where nitrate levels are not well monitored.

The nitrate exported from surface watersheds is typically a mixture of nitrate from two sources:

(1) Atmospheric deposition (atmospheric nitrate)

(2) Nitrification in soils (microbial nitrate)

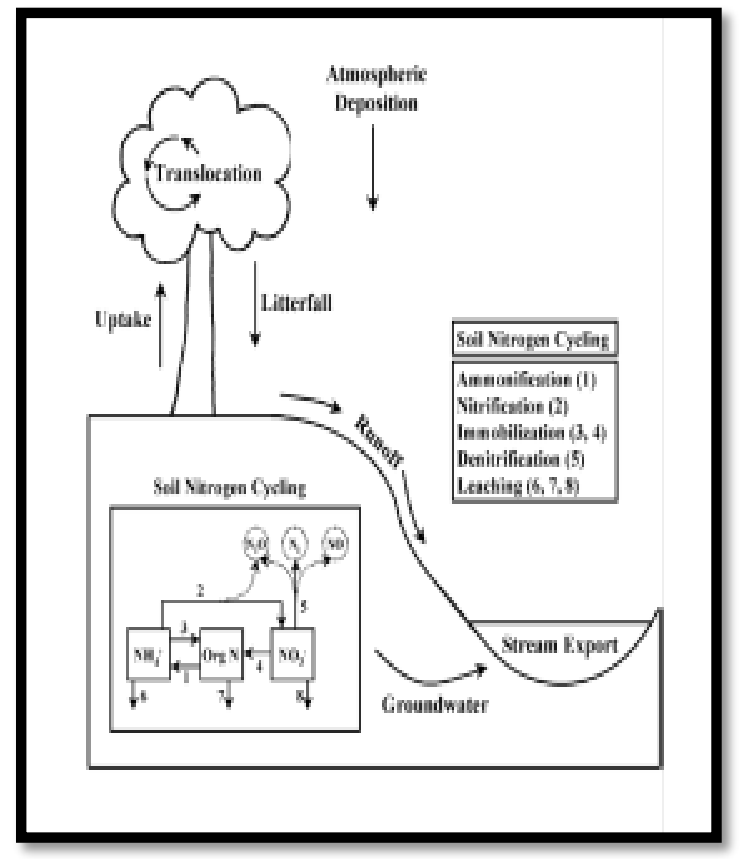

Fig 1. Diagrammatic representation of the major Components of the Nitrogen cycle

Stable nitrogen and oxygen isotopes are useful in indicating sources when nitrate is present in surface or groundwater. Delta nitrate-nitrogen ( $\delta 15 \mathrm{Nnitrate})$ and nitrate-oxygen ( $\delta 18$ Onitrate) isotope ratios in water can be used to identify nitrate sources and its fate in shallow groundwater. Nitrogen has two stable isotopes: $14 \mathrm{~N}$, with a natural abundance of $99.63 \%$ and $15 \mathrm{~N}$, with a natural abundance of $0.37 \%$. The wide difference in the isotopic abundance allows for the determination of distinctive isotopic 
signatures to define specific natural and anthropogenic sources. In analyzed samples, the ratio of $15 \mathrm{~N} / 14 \mathrm{~N}$ is compared with a standard (atmospheric nitrogen) to provide $\delta 15 \mathrm{~N} *$. The abundance of $15 \mathrm{~N}$ in the atmosphere remains relatively constant because of the inert character of atmospheric nitrogen resulting in a $\delta 15 \mathrm{~N}$ of zero.

\begin{tabular}{|c|c|c|c|c|c|}
\hline Isotope & $\begin{array}{l}\text { Method } \\
\text { of } \\
\text { Analysis }\end{array}$ & $\begin{array}{l}\text { Analyti } \\
\text { cal } \\
\text { precisi } \\
\text { on }\end{array}$ & $\begin{array}{l}\text { Sample } \\
\text { amount }\end{array}$ & $\begin{array}{l}\text { Field } \\
\text { measure } \\
\text { ment, } \\
\text { Preservat } \\
\text { ion and } \\
\text { sampling } \\
\text { bottle }\end{array}$ & storage \\
\hline $15 \mathrm{~N}$ & IRMS & $\begin{array}{l} \pm \\
\underline{0.2 \% 0}\end{array}$ & $4 \mathrm{mg} \mathrm{N} 2$ & $\begin{array}{l}\text { Acidifica } \\
\text { tion to } \\
\text { PH } 2 \text { with } \\
\text { HCL, } \\
\text { Glass } \\
\text { bottle }\end{array}$ & $\begin{array}{l}3 \\
\text { months }\end{array}$ \\
\hline $18 \mathrm{O}$ & IRMS & +0.5 & $25 \mathrm{mg} \mathrm{N} 03$ & $\begin{array}{l}\text { Acidifica } \\
\text { tion to } \\
\text { PH 2 with } \\
\text { HCL, } \\
\text { Glass } \\
\text { bottle }\end{array}$ & $\begin{array}{l}3 \\
\text { months }\end{array}$ \\
\hline
\end{tabular}

Table 1. Stable isotopes, (Analytical Method)

\subsection{Objectives}

To assess the source of Nitrate pollution in shallow aquifer in urban and rural area.

Using remote sensing and GIS For Acquire data and displaying spatial data for investigating environmental pollution hazard.

\subsection{Site description and methods}

Sudan land cover image and landsat mosaic image which acquired in 2013 with resolution 30 meter, and projected: WGS_1984_UTM_Zone_36N. This image was classified to create land use and land cover maps for tow selected study area, Khartoum state with population more than 5 million, and Bara locality as rural area with small population their livelihood mainly from small farms (vegetables and fruits), and livestock . They used shallow boreholes for irrigation and drinking water supply.

\subsection{Special analysis using interpolation method}

Inverse distance weighting (IDW):-In interpolation with IDW method, a weight is attributed to the point to be measured. The amount of this weight is dependent on the distance of the point to another unknown point the distance between the points count, so the points of equal distance have equal weights. The weight factor is calculated with the use of the following formula:

$$
\lambda_{i}=\frac{D_{i}^{-\alpha}}{\sum_{i=1}^{n} D_{i}^{-\alpha}}
$$

Where:

$\lambda_{i}$ the weight of the point $\mathrm{Di}$-Distance between point I and unknown point a - The power ten of weight.

Typical $\hat{\delta}^{15} \mathrm{~N}$ and $\hat{\delta}^{18} \mathrm{O}$ Values in Dissolved Nitrate $\left(\mathrm{NO}_{3}\right)$
\begin{tabular}{|l|c|c|}
\hline \multicolumn{3}{|c|}{ From Different Nitrate Sources } \\
\hline Potential Contaminant Source & ${ }^{15} \mathrm{~N}(\%)$ & ${ }^{18} \mathrm{O}(\%)$ \\
\hline Commercial fertilizer & -4 to +4 & +18 to +26 \\
\hline Animal or human waste & $>+10$ & -4 to +12 \\
\hline Precipitation & -3 & +18 to +60 \\
\hline Organic nitrogen in soil & +4 to +9 & +1 to -4 \\
\hline
\end{tabular}

Table 2. Vienna Standard Mean Ocean Water (VSMOW) standards for $\delta 15 \mathrm{~N}$ and $\delta 18 \mathrm{O}$

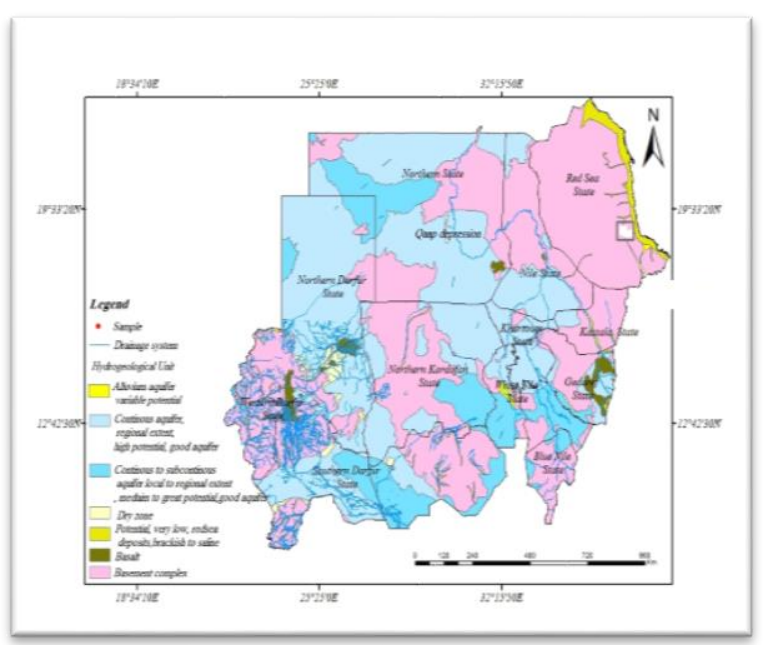

Fig 2. Sudan hydro Geological map show, Khartoum and N. Kordofan state

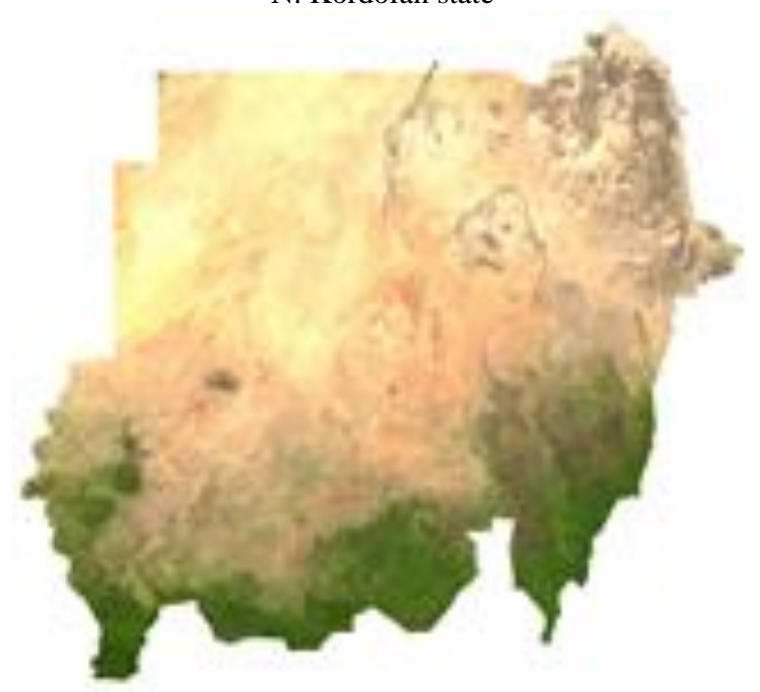

Fig 3. Sudan land cover image

\section{KHARTOUM STATE LAND COVER AND LAND USE MAP}

Created from land sat mosaic image 2013, and classify using ERDAS imagine 8.5 software (2014).

The classification process used by sorting pixels into a finite number of individual classes, if a pixel satisfies a certain set of 
criteria, then the pixel is assigned to the class that corresponds to those criteria.

ERDAS software has two ways to classify pixels into different categories, supervised and unsupervised.

Study area land use created using supervised classification which more closely controlled than unsupervised .In this process, we select pixel that represent patterns you recognize or can identify with help from knowledge of the data, the classes desired, and the algorithm to be used is required.

By identifying patterns in the imagery, we can train the computer system to identify pixels with similar as they are assigned to a class value. If the classification is accurate, then each resulting class corresponds to a pattern that we originally identified.

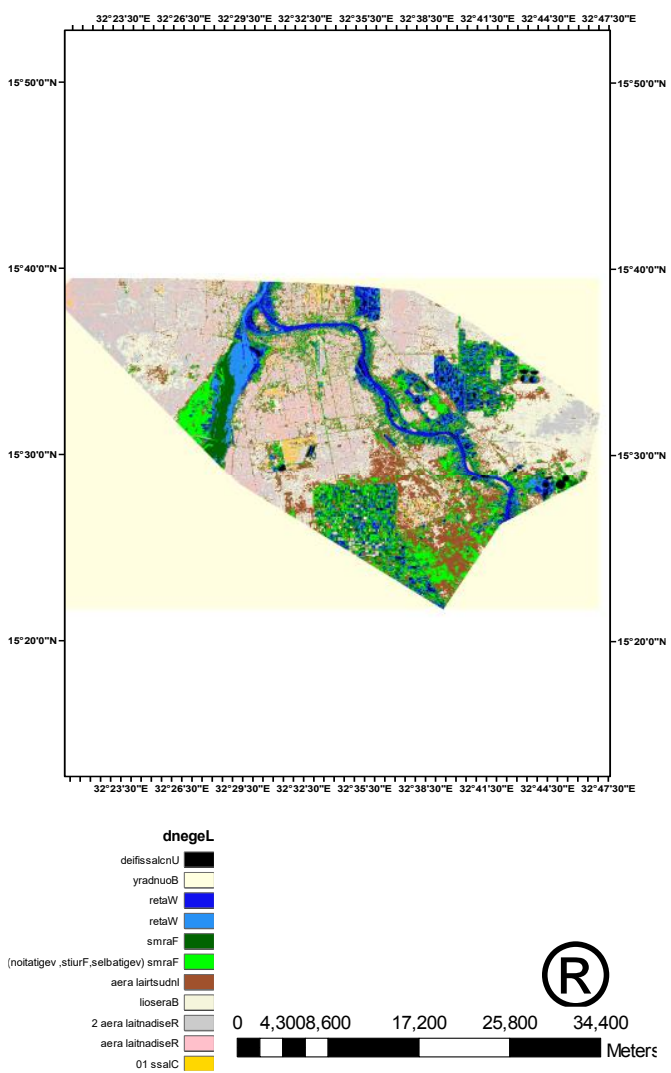

Fig 4. Khartoum land use map

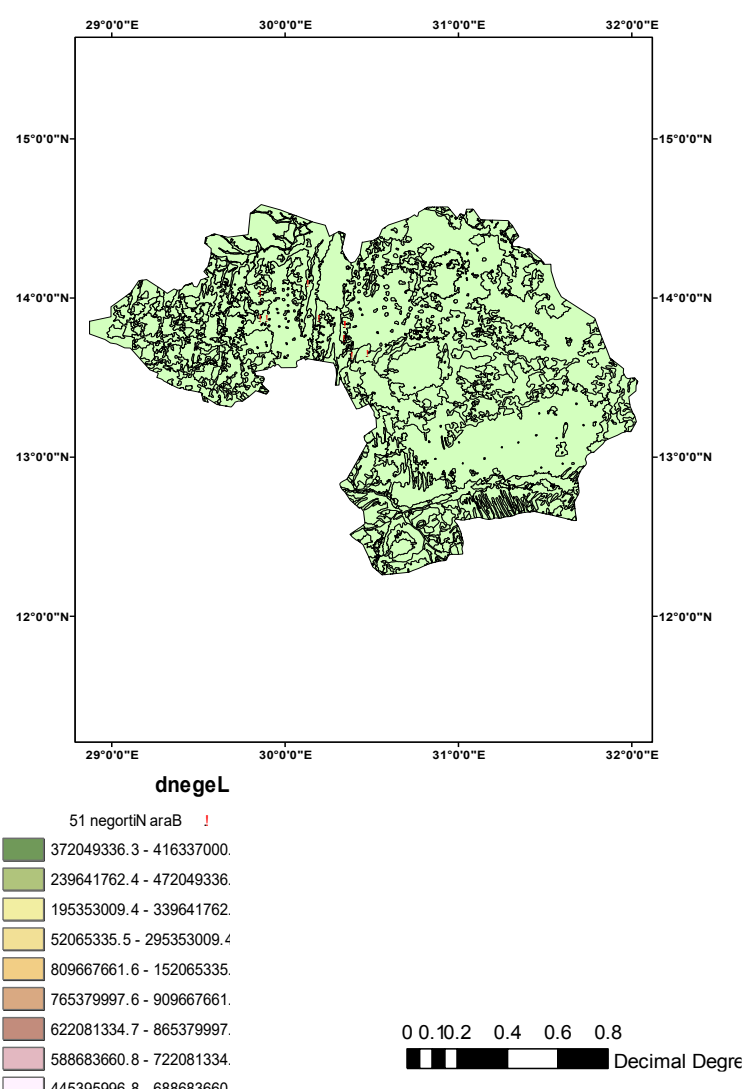

Fig 5. N-Kordofan, Bara land cover \& $15 \mathrm{~N}$

\section{RESULT}

All isotopic ratios were determined at the Environmental Isotope Lab (EIL) and are reported in delta $(\delta)$ notation in units of per mile (\%o) relative to atmospheric N2 (Air) and Vienna Standard Mean Ocean Water (VSMOW), and supported by SUD8010y project in (table 3,4$)$ standards for $\delta 15 \mathrm{~N}$ and $\delta 18 \mathrm{O}$, respectively (Table2).

Result of nitrate isotopes analysis for sample collected from shallow aquifer in Khartoum indicated the source of nitrate contamination was from anthropogenic source and mainly from animal or human waste and organic nitrogen in soil. If we compare the result with special analysis result and land cover/ land use map for Khartoum area, the population increase which lead to increase in human waste water with low facilities for treatment .also nitrate contamination increase in shallow aquifer during rainfall season by percolation into the soil to ground water .

For Bara area were samples collected from 11 shallow Boreholes, the result of analysis indicated that the nitrogen sources mainly from organic nitrogen in soil and commercial fertilizer, which agree with special analysis and land cover map the $90 \%$ land use area farms planted with vegetables and fruit, and they used intensive fertilizers see appendix (1) (Table 3). 
The International Archives of the Photogrammetry, Remote Sensing and Spatial Information Sciences, Volume XLII-3, 2018 ISPRS TC III Mid-term Symposium "Developments, Technologies and Applications in Remote Sensing", 7-10 May, Beijing, China

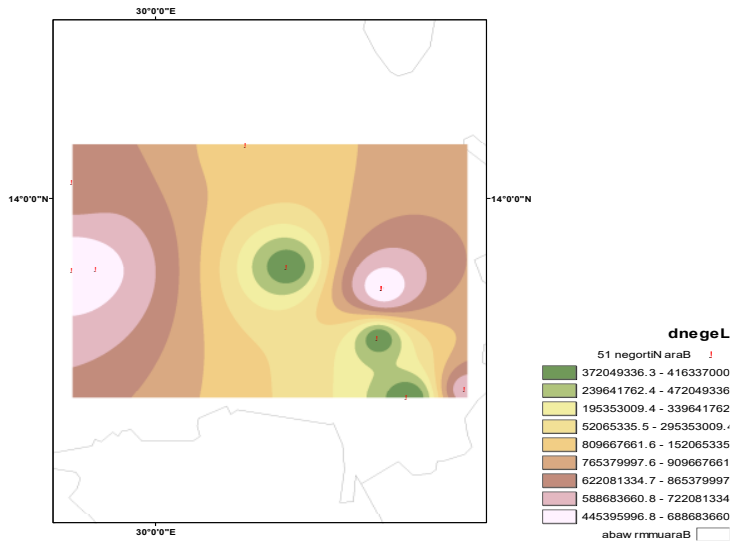

Fig 6.N-Kordofan, Bara- Nitrogen15 Distribution Using IDW Interpolation
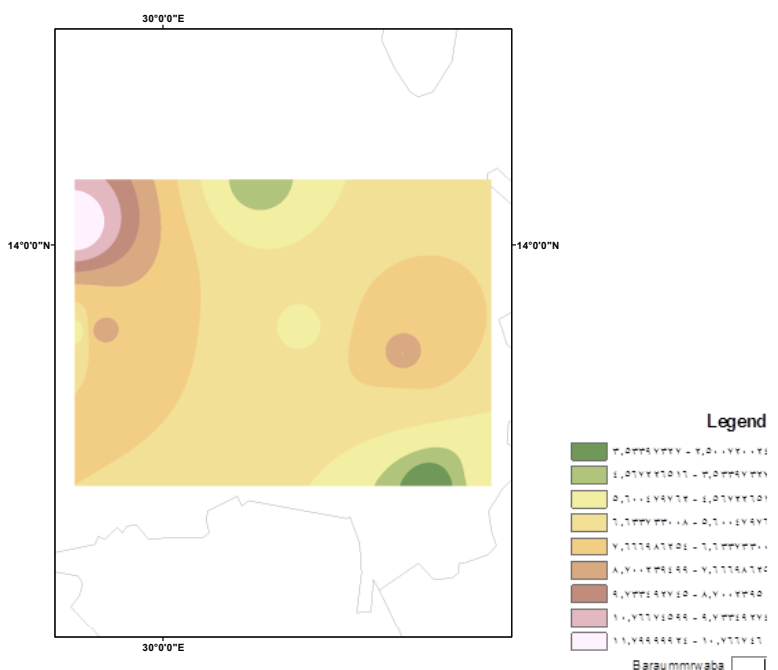

Fig 7.N-Kordofan, Bara- $\delta 180$-nitrate distribution Using IDW Interpolation

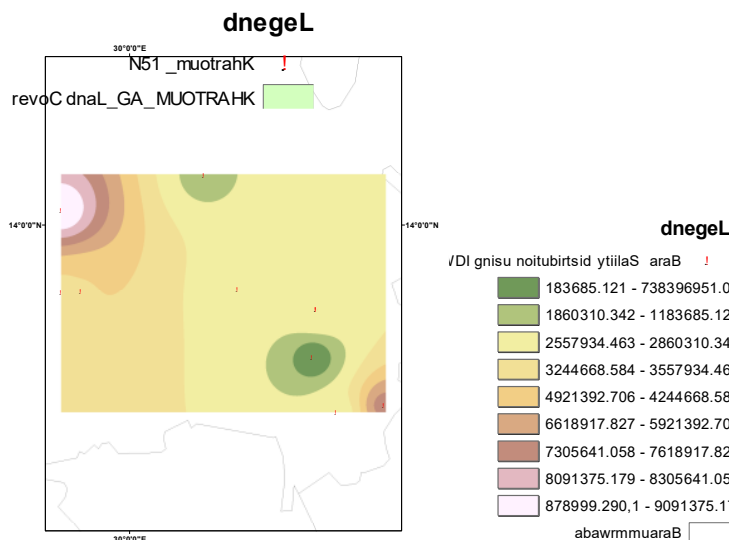

Fig 8. Bara salinity map

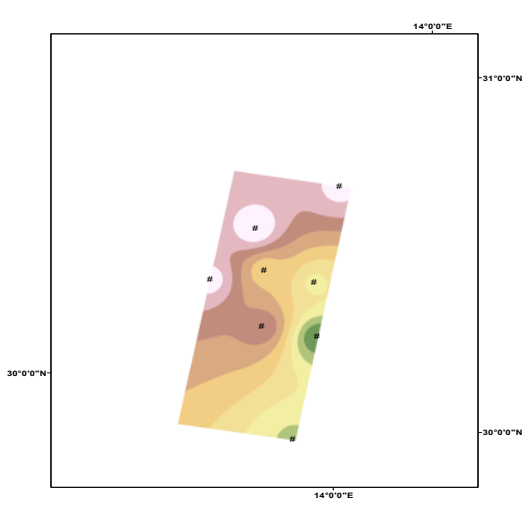

Fig 9. Bara Nitrate $\left(\mathrm{NO}_{3}\right)$ concentration $\mathrm{mg} / \mathrm{l}$

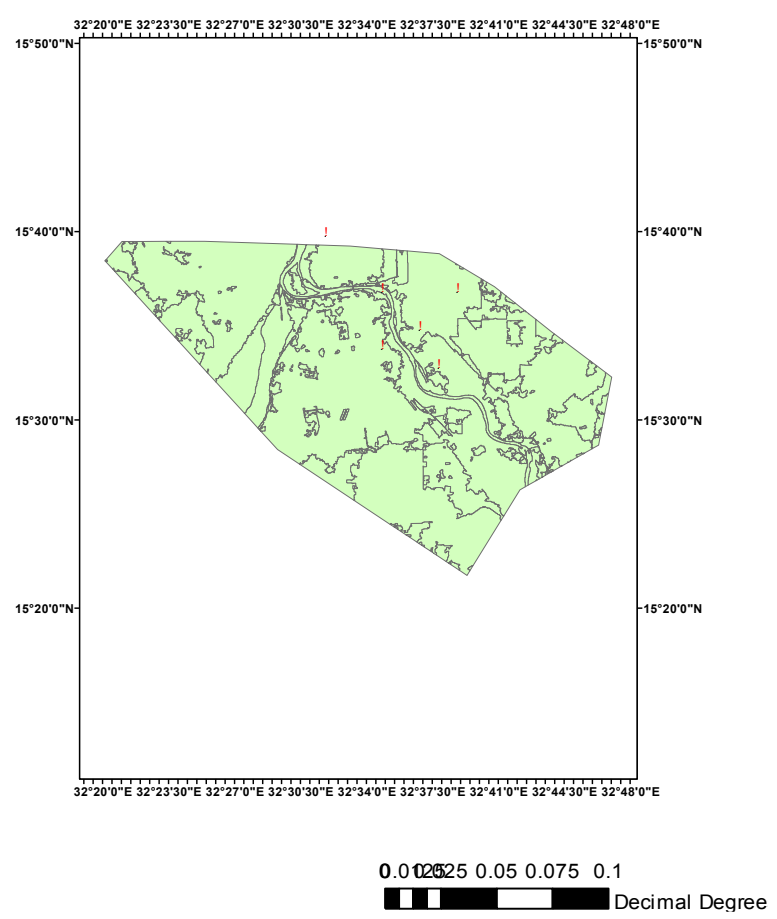

Fig10. Khartoum Land cover and shallow boreholes special location 

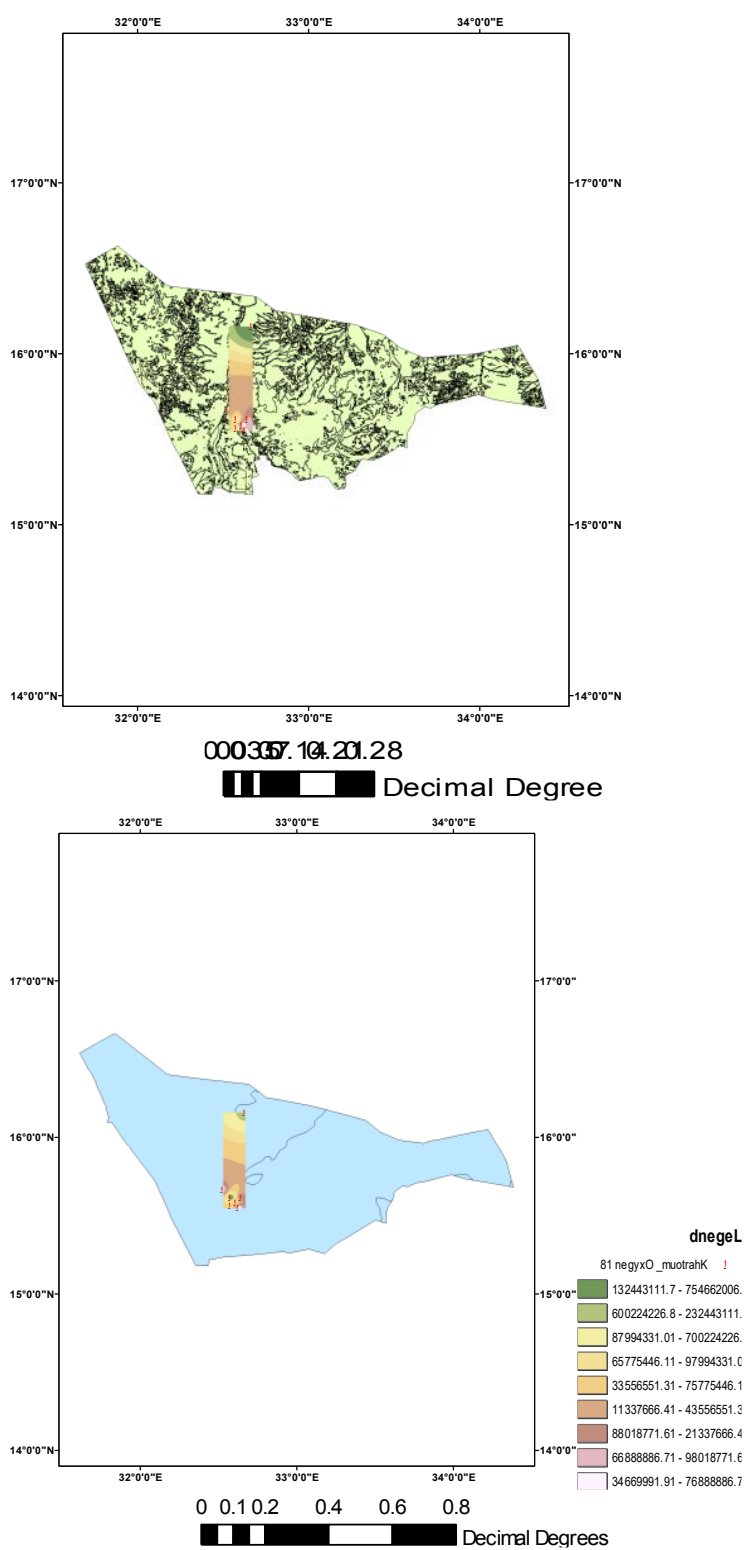

Fig 11. Khartoum -hydro geological -Oxygen 18 animal and human waste, while in Bara basin shallow boreholes, the nitrate contamination source mainly organic nitrogen in soil, like fertilizers in agriculture farm, and few contaminated by livestock area and urban area mainly human waste. Most nitrate contamination sources are easily defined, particularly there is single known source such as a cattle feed lot, but in some areas particularly rural locations that have been urbanized, distinguishing between human (anthropogenic) and natural (geogenic) sources is somewhat more complicated

Analysis of nitrogen-oxygen isotopes of dissolved nitrate provides an excellent technique for Fingerprinting nitrate sources, however, as in any forensic investigation it is important to have more than one line of evidence and the technique combined with a complete understanding of the local environment or land use history and hydrogeology including groundwater geochemistry.

\section{ACKNOWLEDGEMENTS}

I owe my deepest gratitude to my supervisor's and colleague in Ground water and wades Geo-information centre whom has extremely supportive.

\section{REFERENCES}

Mahvi, A. H., Nouri, J., Babaei, A. A., \& Nabizadeh, R, 2005. Agricultural activities impact on groundwater nitrate pollution. In: International Journal of Environmental Science \& Technology, 2(1), pp.41-47.

Ihlenfeld, C., Oates, C. J., Bullock, S., \& Zyl, R. V. . Isotopic fingerprinting of groundwater nitrate sources around anglo platinum's rpm mogalakwena operation (limpopo province, south africa). Imwa Info.

Voudouris, K., Panagopoulos, A., \& Koumantakis, I, 2004. Nitrate pollution in the coastal aquifer system of the korinthos prefecture. Global Nest Journal. 6(1), pp31-38.

Ritchie, J. C.,2015. Remote sensing techniques to assess water quality. Photogrammetric Engineering \& Remote Sensing, 69(6), pp.695-704.

\section{CONCLUSIONS}

The result of analysis compared with land use map and special distribution of nitrate indicated that $85 \%$, and $75 \%$ of samples collected from Khartoum state, fingerprinting nitrate source from 
The International Archives of the Photogrammetry, Remote Sensing and Spatial Information Sciences, Volume XLII-3, 2018 ISPRS TC III Mid-term Symposium "Developments, Technologies and Applications in Remote Sensing", 7-10 May, Beijing, China

\section{APPENDIX}

\section{Appendix 1}

\begin{tabular}{|l|l|l|l|l|l|l|l|l|}
\hline Sample code & LONGT:DC & LATIT:DC & E C $\mu \mathrm{s} / \mathrm{cm}$ & PH & $\begin{array}{l}\text { Nitrate } \\
\text { as N2 }\end{array}$ & $\delta^{15} \mathrm{~N}_{\text {nitrate }}$ & $\delta^{18} \mathrm{O}_{\text {nitrate }}$ & Source of Pollution \\
\hline ( local ) & & & & & & {$[\%$ air $]$} & {$[\%$ ovsmow $]$} & \\
\hline B-004 & 13.64063 & 30.39779 & 295 & 7.9 & 40.172 & 3.0 & 2.5 & commercial fertilizer \\
\hline B-006 & 13.8953 & 30.00365 & 275 & 8.7 & 34.23 & 9.4 & 10.9 & organic nitrogen in soil \\
\hline B-007 & 14.0287 & 29.87027 & 1093 & 8.1 & 75 & 7.0 & 11.8 & organic nitrogen in soil \\
\hline B-008 & 13.87109 & 29.90911 & 448 & 8.3 & 6.7 & 8.7 & 5.0 & organic nitrogen in soil \\
\hline B-009 & 13.87226 & 29.90793 & 481 & 8.7 & 64.3 & 8.2 & 8.1 & organic nitrogen in soil \\
\hline B-010 & 14.09616 & 30.14425 & 189 & 8 & 4.3 & 5.9 & 4.1 & organic nitrogen in soil \\
\hline B-011 & 13.87634 & 30.20843 & 291 & 8.1 & 15.6 & 3.1 & 5.4 & commercial fertilizer \\
\hline B-012 & 13.7473 & 30.35191 & & & 45.35 & 3.1 & 5.6 & commercial fertilizer \\
\hline B-013 & 13.8375 & 30.35862 & 93.6 & 8.4 & 11.2 & 10.4 & 9.1 & animal or human waste \\
\hline B-014 & 13.83741 & 30.35864 & 583 & 7.7 & 24.5 & 6.6 & 6.6 & organic nitrogen in soil \\
\hline B-015 & 13.65482 & 30.48944 & 794 & 8.7 & 22.93 & 7.9 & 5.2 & organic nitrogen in soil \\
\hline
\end{tabular}

Table (3) Stable Isotopes Result and Source of pollution 
The International Archives of the Photogrammetry, Remote Sensing and Spatial Information Sciences, Volume XLII-3, 2018 ISPRS TC III Mid-term Symposium "Developments, Technologies and Applications in Remote Sensing", 7-10 May, Beijing, China

\section{Appendix 2}

\begin{tabular}{|c|l|l|r|r|l|}
\hline Sample code & LONGT:DC & LATIT :DC & \multicolumn{1}{l|}{$\delta^{15} \mathrm{~N}_{\text {nitrate }}$} & \multicolumn{1}{l|}{$\delta^{18} \mathrm{O}_{\text {nitrate }}$} & Source / \\
\hline $\begin{array}{c}\text { ( local ) } \\
\text { KHRT- 001 }\end{array}$ & 32.6737 & 16.1611 & 6.2 & 8.3 & organic nitrogen in soil \\
\hline KHRT- 002 & 32.65 & 15.616667 & 15.4 & 15.7 & animal or human waste \\
\hline KHRT- 003 & 32.63333 & 15.55 & 16.9 & 19.2 & animal or human waste \\
\hline KHRT- 004 & 32.583333 & 15.616667 & 9.2 & 5.6 & organic nitrogen in soil \\
\hline KHRT- 006 & 32.583333 & 15.566667 & 8.8 & 11.6 & organic nitrogen in soil \\
\hline KHRT- 007 & 32.616667 & 15.583333 & 17.7 & 11.8 & animal or human waste \\
\hline KHRT- 008 & 32.533333 & 15.666667 & 13.6 & 17.4 & animal or human waste \\
\hline
\end{tabular}

Table 4. Result of $\delta^{\mathbf{1 5}} \mathbf{N}_{\text {nitrate and }} \delta^{\mathbf{1}} \mathbf{O}_{\text {nitrate }}$, Bara 